\title{
Analysis of Online Learning Implementation in Undergraduate Students of Building Construction Education in the Pandemic COVID-19
}

\author{
Kusnan ${ }^{1, *}$ Suparji ${ }^{1}$ Gde Agus Yudha Prawira Adistana ${ }^{1}$ Muhammad Imaduddin ${ }^{1}$ \\ Wahyu Dwi Mulyono ${ }^{1}$ Heri Suryaman ${ }^{1}$
}

\author{
${ }^{1}$ Department of Civil Engineering, Universitas Negeri Surabaya, Surabaya, Indonesia \\ ${ }^{*}$ Corresponding author. Email: kusnan@unesa.ac.id
}

\begin{abstract}
Surabaya State University (Unesa) as an educational actor limits physical distance by implementing online learning activities to break the spread of COVID-19. Online learning is usually carried out at a maximum of three meetings and combined with face-to-face. However, in the even semester 2019/2020 Unesa conducted full online learning starting on March 14, 2020. Full online learning demands lecturers' creativity in using appropriate learning methods and media. In line with this, it is necessary to analyze the implementation of online learning. This study aims to analyze the implementation of online learning that was carried out on students during the COVID-19 Pandemic. This research is a descriptive study with a quantitative approach. The respondents of this study were students in the S1 Building Engineering Education study program (PTB) at the Faculty of Engineering, Unesa. Data collection using a questionnaire with a Likert scale. Data analysis techniques using quantitative descriptive techniques. The results showed that (1) students still felt less interested in online learning; (2) independent learning makes students not understand the material; (3) the method deemed most appropriate according to students is to use online discussion and guidance; and (4) the biggest obstacle in online learning is the condition of the weak internet network in the student area. The constraints experienced in online learning are the internet network and the difficulty of controlling student activity, honesty, and authenticity in improving student learning outcomes.
\end{abstract}

Keywords: analysis, COVID-19, implementation, online learning, students of Building Engineering Education

\section{INTRODUCTION}

By observing the development of changes in the status of COVID-19 infection into a pandemic, the Surabaya State University determined that the COVID-19 Spread Prevention Measures take effect starting on March 14, 2020 based on the Chancellor Circular Letter Number B/15254/UN38/ TU.00.02/2020 [1]. In the Circular, stipulates the following matters: (a) Theory (face-to-face, structural tasks and independent assignments) is carried out with E-learning, WA groups, Line, Skype, or the like; (b) Practicum (laboratory, workshop, studio, microteaching) is carried out by giving other relevant assignments in accordance with learning achievements; (c) Field (KKN, PKL, PI, PLP, Internship, Student/Lecturer Exchange, etc.) temporarily compensated in the form of other activities; (d) Exams are conducted online;

(e) Final assignment, thesis, thesis, and dissertation guidance can be carried out online; and (f) Proposal exams, final assignment exams, thesis exams, thesis exams, compress tests, closed exams, and open exams may still be held but only be attended by students who are tested and testers who have met the WHO protocol or can be done online.

In its implementation, the online learning activities of theoretical and practical lectures in the laboratory that have been carried out have received criticism from students through an open letter from the Student Representative Council of the Faculty of Engineering 
,State University of Surabaya Number: 09 / ST / DPM-FT /VI/2020 [2]. The criticism is related to the implementation of online learning related to the number of assignments to student health considerations, lecture activities carried out, constraints on the learning tools used, and technological means to support learning activities for students to access. Various kinds of online learning are used by lecturers, of course not all are the same between one lecturer and another. Other previous research related to the implementation of learning, analysis of learning implementation and the constraints of learning implementation have been carried out [3]. So that a more in depth analysis and study is needed regarding the implementation of online learning carried out for undergraduate students. Other previous studies related to the analysis of learning implementation, the results of the implementation of reasoning learning activities are not optimal [4]. Other research related to implementation analysis, namely the analysis of the iplementation of E-Learning using group costs in applying to tertiary education the total cost is also determined by the number of users [5].

The formulation of the problem in this research is how was the result of the implementation of the online learning process during the COVID-19 pandemic period in S1-PTB students of the Department of Civil Engineering, Faculty of Engineering Unesa.The purpose of this study was to determine the results of the implementation of online learning conducted at PTB undergraduate students including the implementation of online learning processes during the COVID-19 pandemic.

Education will not be separated from the process of learning and learning. Learning is a relatively permanent change in behavior as a result of the experience or training done. Learning is a result of the interaction between stimulus and response [6]. Learning is the process of interaction of students (students) with educators (lecturers) and learning resources in a learning environment. Learning is an accumulation of teaching concepts and learning concepts [7]. Learning shows the students' efforts to learn subject material as a result of the treatment of educators. The role of educators here differs in their roles between then and now. Educators initially as a primary learning resource for students, but now are different, namely as a facilitator who directs learning activities [8].

There are advantages and disadvantages of online learning. One of the advantages of online learning is that material and learning can be accessed anytime and anywhere provided there is a good internet connection. Online learning media are very varied and interesting depending on the creativity of educators in managing learning. The weakness of online learning is very much dependent on the availability of an internet connection, if there is no internet connection it will not be able to access learning. Assessment also can't be directly supervised properly and cheating can be done by students who are not good.

Online learning needs to be well planned so that it can be implemented to achieve learning objectives. The choice of media, audio, video letters, and images also influences the effectiveness of the learning. Integration between various media is needed so that online learning can run well. Online learning must be adapted to learning material [9]. Online learning has a wide reach with a high degree of flexibility. Timeliness can be maintained by implementing an ontime system in assigning assignments or evaluating learning. Online learning requires independent and active learners to access material and exercises. Students will also be encouraged to improve their problem solving skills independently [10]. Online learning can also be done with social media. Social media like Facebook, WhatsApp, Telegram and so on can be managed into learning media. Every student must have social media in accordance with technological advances in the present. Good management and use of social media as learning media can be done as an alternative in online learning [11].

Lecturers' tasks in learning include involving students to be active in the learning process directly. Lecturers play a role as facilitators in learning activities must be able to provide motivation, encouragement, guidance and reinforcement material for students. In previous studies related to the implementation of learning, this study found inhibiting factors include time constraints, students are less active, and the use of learning models and strategies. Obtained a good response from the implementation of learning activities from students [3]. Other previous studies related to the analysis of the implementation of learning, showed that the implementation of scientific learning included in the high category [12]. The results of other studies indicate that the implementation of learning activities that are structured properly can increase the effectiveness and quality of teaching [13]. In the implementation of learning implementation must be in accordance with what has been planned in the learning plan so that learning objectives can be achieved to the maximum. RPS (semester learning plans) must be systematic so that they can be easily implemented and understood.

From the description above explains that online learning is the interaction between educators and students and learning resources conducted online. There are various kinds of media that can be used in online learning such as E-learning, google classroom, google meet, zoom and social media such as Facebook, Whatsapp, telegram and so on. The main factors in the success of learning are educators (lecturers) and students (students). Educators must be able to manage and make good online media in accordance with the material to be delivered. Students 
must be active and disciplined in carrying out learning and have high honesty.

Evaluation is a process of comparing results with goals or objectives. Evaluation is a systematic assessment of the superiority of an object, action or process to determine the value of a product from the process. Evaluation in school or college is assessing the implementation and learning outcomes. Evaluation in a laboratory also includes monitoring the results of conducting experiments. Evaluation is used to determine whether goals or objectives are achieved or not [14]. Evaluation of a program not only looks at the results, but also the objectives, structure, and process. Evaluation will not succeed if you only see the results without seeing the process. The structure of a good program, good goals, good processes, is able to realize good results.

Evaluation results must be delivered on time for future program planning so that the results are better. Like a cycle of action research that needs reflection on the results of the evaluation. The reflection is used immediately to re-plan and be carried out again with improvements from the previous cycle. There are two types of evaluation, formal and informal. Formal evaluation has clear standards, assessment criteria and processes and techniques. Informal evaluation is carried out daily by monitoring the situation or a program in general without any specific standards or criteria. The main criteria in evaluating include quality, performance, side effects or effects, effectiveness, safety, sustainability, ability, and so on. The main functions of evaluation are formative (current programs) and summative (final) [14].

One type of evaluation model is CIPP. The scale of the CIPP evaluation model has four factors consisting of context, input, process and product. CIPP as a valid and reliable evaluation instrument can be used in education. The CIPP evaluation model has been widely developed and widely implemented since 1965 [15]. The purpose of the CIPP evaluation model is to look at all the evaluation strategies and components and to find out whether the evaluation design is functioning properly, which parts might be problematic and how to solve them, and whether there are more efficient ways to collect data. The steps in designing each type of evaluation are focusing on evaluating, gathering information, organizing information, analyzing information, reporting information and evaluating administration [15]. The CIPP evaluation model has advantages and disadvantages. The strength of the CIPP model is that it is simple to help evaluators generate questions that are very important to be asked in the evaluation process. The CIPP evaluation model also has several weaknesses, one of which is the inability of evaluators to respond to some significant questions or problems. Evaluators need to consider the resources and time available. The CIPP evaluation model can be an effective model in improving programs. CIPP with a simple instrument is able to obtain data that is already good and needs to be maintained and parts that are not good to be repaired, even parts that need to be replaced or removed.

Research that has been conducted using the CIPP evaluation model to evaluate the reproductive health $\mathrm{PhD}$ program based on the CIPP model with five criteria. The general reproductive health $\mathrm{PhD}$ program is in a fairly appropriate status. The results of the evaluation provide advice to educational policy makers who can pay attention to indicators that are reported appropriately or appropriately enough to develop and improve the $\mathrm{PhD}$ program in reproductive health, maintain and improve indicators that are very precise [16]. Other research uses the CIPP evaluation model with the aim of evaluating the academic advisory program implemented by students at Tehran state universities. To evaluate the program with surveys and instruments in the form of questionnaires. The results of the survey were found in the form of things that are needed and not needed either from input, process, or product [17]

Online learning with e-learning that develops rapidly according to the development of information technology needs to be evaluated to ensure the effectiveness of effectiveness, and the impact on students. The determining factors for the successful implementation of online learning are the quality of the technical system, the quality of information, the quality of services, the quality of the support system, the quality of students, the quality of educators, and the perception of usefulness [18]. An evaluation needs to be done on the implementation of learning. The learning process must always be improved based on the findings or results of the evaluation. Evaluation of the implementation of online learning needs to be done, because it is important for the development of learning.

\section{METHOD}

This type of research is evaluation research. This study provides an overview and evaluation of the results of the implementation of the online learning process during the COVID-19 pandemic period for S1-PTB students in the Department of Civil Engineering, Faculty of Engineering, Unesa. This study uses a questionnaire as a data collection tool to obtain information. The data obtained in the form of quantitative data. The data is then analyzed with quantitative descriptive analysis. The subjects of this study were students in the PTB S1 Study Program. The number of students who were respondents was 71 people.

Data collection techniques in this study used a questionnaire/questionnaire online. Researchers provide systematically arranged questions to obtain data about the implementation of online learning in S1 PTB. Questionnaire preparation was carried out using a Likert scale consisting of five answer choices. The questionnaire 
was developed by the researcher and validated by experts, then used to obtain data from respondents. The instrument was in the form of a questionnaire questionnaire containing several questions relating to the implementation of online learning specifically for the Vilearning, Cisco Webex, Whatsapp, Zoom, Google meet, and Google classroom applications that had been used by lecturers in lectures with students during the COVID-19 pandemic.

Data obtained from this research are in the form of quantitative data. Data analysis techniques using quantitative descriptive analysis techniques. The assessment of online learning implementation in PTB S1 is done by comparing the score of the assessment results with the score of criteria based on the normal curve. Table assessment criteria based on normal curves can be seen in Table 1.

Table 1. Criteria Of Assessment Based On Normal Curve

\begin{tabular}{|l|l|}
\hline Score Range & Criteria \\
\hline $\mathrm{X}>\mathrm{Mi}+1,5 \mathrm{SDi}$ & Very good \\
\hline $\mathrm{Mi}+0,5 \mathrm{SDi}<\mathrm{X} \leq \mathrm{Mi}+1,5 \mathrm{SDi}$ & Well \\
\hline $\mathrm{Mi}-0,5 \mathrm{SDi}<\mathrm{X} \leq \mathrm{Mi}+0,5 \mathrm{SDi}$ & Enough \\
\hline $\mathrm{Mi}-1,5 \mathrm{SDi}<\mathrm{X} \leq \mathrm{Mi}-0,5 \mathrm{SDi}$ & Less \\
\hline $\mathrm{X} \leq \mathrm{Mi}-1,5 \mathrm{SDi}$ & Very less \\
\hline \multicolumn{2}{|l}{ Information : } \\
$\mathrm{Mi} \quad=$ Mean ideal \\
$\mathrm{SDi} \quad=$ Standar Deviasi Ideal \\
$\mathrm{X} \quad=$ Empirical average
\end{tabular}

This research starts from the permit to conduct research and initial research observations. After all is felt to be ready and the initial data obtained from the observation, then the preparation of research instruments is carried out. Validation is required before the instrument is used in data collection. Data collection was performed on S1-PTB students. By using literature study data and the results of data that have been obtained from the implementation of research, then an analysis is carried out on how the results of the implementation of online learning.

\section{RESULT AND DISCUSSION}

\subsection{Result}

This research was carried out in the S1 Building Engineering Education Study Program (S1 PTB) Civil Engineering Department, Faculty of Engineering, Unesa. Respondents were students and lecturers of PTB S1 Study Program who were conducting online learning during the COVID-19 pandemic. Respondent distribution data is presented in Table 2 and Figure 1.
Table 2. Description of research respondents

\begin{tabular}{|c|l|c|}
\hline No & Student Force & Percentage (\%) \\
\hline 1 & S1 PTB 2017 & 41 \\
\hline 2 & S1 PTB 2018 & 20 \\
\hline 3 & S1 PTB 2019 & 39 \\
\hline \multicolumn{2}{c}{ Total } & 100 \\
\hline
\end{tabular}

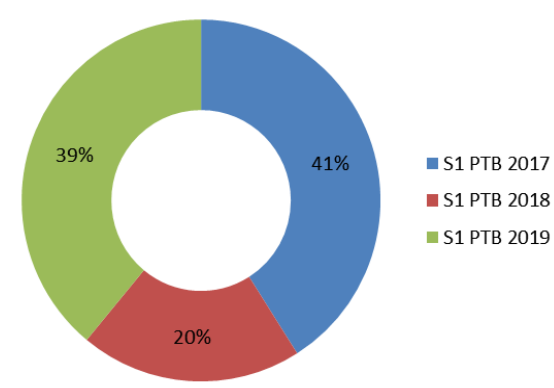

Figure 1. Distribution of research respondents

Student responses to learning motivation get a total score of 931 , with an average number of 13.12. A summary of the data can be seen in Table 3 and Figure 2 .

Table 3. Description of data motivation of student learning Statement item

\begin{tabular}{|c|c|c|c|c|c|}
\hline $\begin{array}{c}\text { Item } \\
\text { Number }\end{array}$ & $\begin{array}{l}\text { Number of } \\
\text { respondents }\end{array}$ & Min & Max & $\begin{array}{l}\text { Amount of } \\
\text { Values }\end{array}$ & Average \\
\hline 1 & 71 & 2 & 5 & 245 & 3,45 \\
\hline 2 & 71 & 1 & 5 & 206 & 2,90 \\
\hline 3 & 71 & 1 & 5 & 173 & 2,44 \\
\hline 4 & 71 & 2 & 5 & 307 & 4,22 \\
\hline \multicolumn{4}{|c|}{ Total } & 931 & 13,12 \\
\hline
\end{tabular}

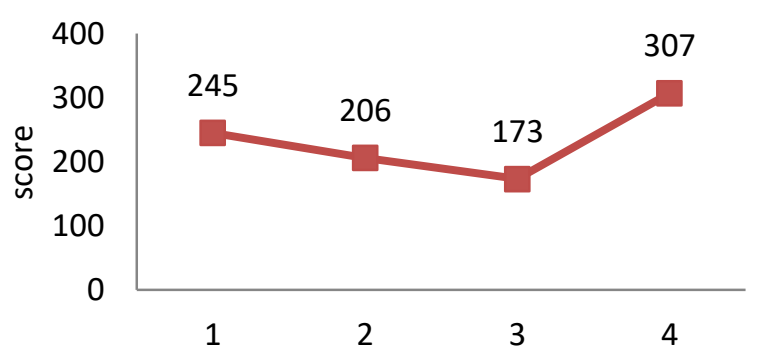

\section{Statement item}

Figure 2. Response to student learning motivation using online learning

Based on Table 3, the average score of students' responses was 13.12 , so that it was included in the sufficient category.

The results of student responses about the most interesting online applications in learning are presented in Table 4 and Figure 3. 
Table 4. Student Response About Online Applications Most Interesting in Learning

\begin{tabular}{|c|l|l|}
\hline No & Online application used & $\begin{array}{c}\text { Percentage } \\
(\%)\end{array}$ \\
\hline 1 & E-learning & 9,3 \\
\hline 2 & Whatsapp & 20,45 \\
\hline 3 & Zoom & 21,45 \\
\hline 4 & Google Classroom & 22,45 \\
\hline 5 & Google meet & 21,45 \\
\hline 6 & Others & 5 \\
\hline \multicolumn{2}{|l|}{ Total } & 100 \\
\hline
\end{tabular}

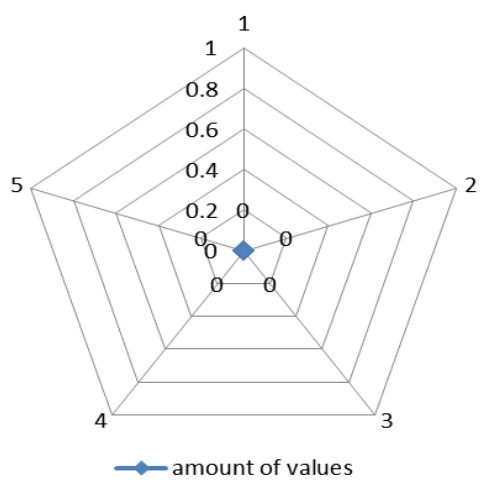

Figure 3. Student responses about online applications After obtaining data using 6 components to describe the implementation of learning. Furthermore, it will be seen that component No. 4 shows the highest value and component No. 1 gets the lowest value.

The results of student responses to the learning implementation component get a total score of 834, with an average number of 24.09. A summary of the data is presented in Table 5 and Figure 4.

Table 5. Description of Data Learning Implementation

\begin{tabular}{|c|c|c|c|c|c|}
\hline $\begin{array}{c}\text { Item } \\
\text { Number }\end{array}$ & $\begin{array}{c}\text { Number of } \\
\text { respondents }\end{array}$ & Min & Max & $\begin{array}{c}\text { Amount of } \\
\text { Values }\end{array}$ & Average \\
\hline 1 & 71 & 1 & 5 & 217 & 3,06 \\
\hline 2 & 71 & 1 & 4 & 175 & 2,04 \\
\hline 3 & 71 & 1 & 5 & 267 & 3,76 \\
\hline 4 & 71 & 1 & 5 & 218 & 3,07 \\
\hline 5 & 71 & 1 & 5 & 244 & 3,44 \\
\hline 6 & 71 & 1 & 5 & 200 & 2,82 \\
\hline 7 & 71 & 1 & 4 & 156 & 2,20 \\
\hline 8 & 71 & 1 & 4 & 234 & 3,30 \\
\hline & \multicolumn{7}{c}{ Total } & 834 & 24,09 \\
\hline
\end{tabular}

Lea

Figure 5. Student Response Components Evaluation and Learning Outcomes

After obtaining data using 8 components to describe the implementation of learning. Furthermore, it will be seen that component No. 2 shows the highest value and component No. 1 gets the lowest value. 
The results of student responses to the components of the problem faced get a total score of 876 , with an average number of 12.34. A summary of the data is presented in Table 7 and Figure 6.

Table 7. Data Description of The Problem

\begin{tabular}{|c|c|c|c|c|c|}
\hline $\begin{array}{c}\text { Item } \\
\text { Number }\end{array}$ & $\begin{array}{c}\text { Number of } \\
\text { respondents }\end{array}$ & Min & Max & $\begin{array}{c}\text { Amount of } \\
\text { Values }\end{array}$ & Average \\
\hline 1 & 71 & 2 & 5 & 309 & 2,86 \\
\hline 2 & 71 & 2 & 5 & 316 & 3,39 \\
\hline 3 & 71 & 2 & 5 & 251 & 2,89 \\
\hline \multicolumn{2}{|c|}{ Total } & & & 876 & 12,34 \\
\hline
\end{tabular}

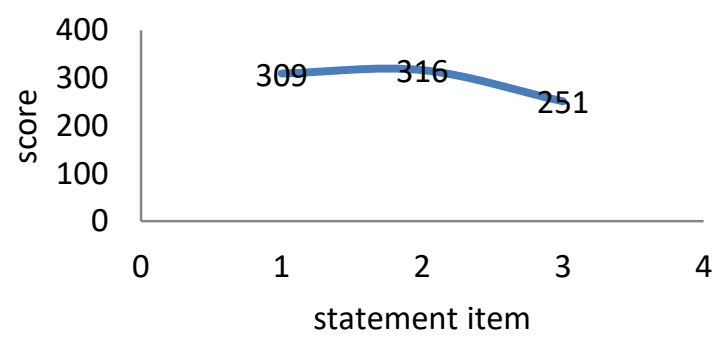

amount of values

Figure 6. Student responses to problems encountered in online learning

\subsection{Discussion}

The results of student responses from the questionnaire consisted of five components showing that:

a. The result of student responses to the most interesting online applications in learning is the google classroom with $22.45 \%$.

b. The results of students' responses to the implementation of learning indicate that there is an increase in student independence in learning, but overall the implementation of online learning is still less than optimal and needs to be increased again. Students seem to be unfamiliar with learning on their own and prefer to have direct interaction with lecturers and other students.

c. Student responses to evaluations and learning outcomes related to online learning assessment techniques are appropriate, however, students still find it difficult to do the exercises, students also feel their grades are not increasing.

d. Student responses about problems encountered when using online applications get very high criteria. Based on these results the students in the implementation of online learning are still not good, management, media, evaluation of each need to be improved, it is also in line with the high problems faced by both the signal, the cost of internet pulses, and devices that are less supportive.

\section{CONCLUSION}

Based on data analysis and discussion, it can be concluded that online learning in the PTB S1 Department of Civil Engineering, Faculty of Engineering Unesa during the COVID-19 pandemic still needs to be improved. The results of student responses showed that of the five components, four components received sufficient criteria, namely self motivation, online application media, implementation of learning, evaluation and learning outcomes, and components of the problems encountered were very high criteria. The results of lecturers' responses to the implementation of online learning from the five components of one component get good criteria, namely learning planning, three components with enough categories, namely online application media, learning implementation, evaluation and learning outcomes, and the fifth component, namely the problems faced to get high criteria. The results of the lecturers 'and students' responses show the same thing, namely the implementation of online learning needs to be improved and the problem faced need to be minimized in order to improve learning outcomes.

\section{ACKNOWLEDGMENT}

We express our gratitude to the Chancellor, Dean of Faculty of Engineering, and Chairperson of LPPM Unesa for providing the opportunity to conduct research on the analysis of online learning implementation.

\section{REFERENCES}

[1] Nurhasan, "SE REKTOR TENTANG COVID-19.pdf." Universitas Negeri Surabaya, 2020.

[2] A. C. Putra, Surat Dewan Perwakilan Mahasiswa Fakultas Teknik Unesa, no. April. 2020.

[3] H. Sabdhosih and W. Isnaeni, "Journal of Innovative Science Education Analysis of Implementation Plan of Science Learning and the Factors of Its Implementation in MTs and MA Al Khoiriyyah Semarang," $J$. Innov. Sci. Educ., vol. 7, no. 2, pp. 160-168, 2018.

[4] S. Effendy, F. Mudhofir, and I. Yulianti, "Journal of Innovative Science Education Analysis of the Implementation of Reasoning Learning Based on the Scientific Approach in Physics Learning," J. Innov. 
Sci. Educ., vol. 8, pp. 49-54, 2019.

[5] A. Nikolopoulos, J. W. Goethe-universität, J. W. Goethe-universität, A. Nikolopoulos, R. Holten, and J. W. Goethe-universität, "Analysis of E-Learning Implementation Cost Pools," in ACIS 2007 Proceedings, 2007.

[6] R. E. Slavin, "Education Psychology: Theory and Practice." 2018.

[7] M. Suardi, Belajar dan Pembelajaran. 2018.

[8] M. Faturohman, Belajar dan Pembelajaran Modern Konsep Dasar, Inovasi, dan Teori Pembelajaran. 2017.

[9] V. Sahasrabudhe and S. Kanungo, "Computers \& Education Appropriate media choice for e-learning effectiveness : Role of learning domain and learning style," Comput. Educ., vol. 76, pp. 237-249, 2014.

[10] F. Qing and L. Li, "Web-based Collaborative Learning," in Procedia Environmental Sciences, 2011, vol. 11, pp. 189-192.

[11] W. M. Al-rahmi and A. M. Zeki, "A model of using social media for collaborative learning to enhance learners ' performance on learning," J. King Saud Univ. - Comput. Inf. Sci., no. September, 2016.

[12] R Qadar and Z. Haryanto, "Analysis of scientific learning implementation by science teachers in Analysis of scientific learning implementation by science teachers in Samarinda," J. Phys. Conf. Ser., 2019.

[13] M. A. Hamid, S. U. Rizal, S. N. Muhammad Nurtanto, M. Fawaid, A. Rahmat, and A. Mutolib, "The Analysis of Learning Implementation Plan ( LIP ) in Vocational Subjects Based on 2013 Curriculum," Adv. Soc. Sci. Educ. Humanit. Res., vol. 161, no. Iciser 2017, pp. 27-32, 2018.

[14] Daniel L., Stufflebeam, and A. J. Shinkfield, "Evaluation Theory, Models, \& Applications," J. Multidiscip. Eval., vol. 6, no. 11, pp. 2007-2009, 2009.
[15] K. Hakan and F. Seval, "CIPP evaluation model scale: development, reliability and validity," Procedia - Soc. Behav. Sci., vol. 15, pp. 592-599, 2011.

[16] M. Abdishahshahani, S. Ehsanpour, N. Yamani, and S. Kohan, "The Evaluation of Reproductive Health PhD Program in Iran : A CIPP Model Approach," Procedia - Soc. Behav. Sci., vol. 197, no. February, pp. 8897, 2015.

[17] K. Allahvirdiyani, "Evaluate Implemented Academic Advisor of Shahed Students in Tehran State Universities Through CIPP Evaluation Model," Procedia - Soc. Behav. Sci., vol. 15, pp. 2996-2998, 2011.

[18] D. Al-fraihat, M. Joy, and J. Sinclair, "Computers in Human Behavior Evaluating E-learning systems success: An empirical study," Comput. Human Behav., vol. 102, no. March 2019, pp. 67-86, 2020. 